\title{
Trace Metals and Mineral Composition of Harmattan Dust Haze in Ilorin City, Kwara State, Nigeria
}

\author{
${ }^{1}$ FALAIYE, OA; ${ }^{* 2}$ AWEDA, FO \\ ${ }^{I}$ Department of Physics, University of Ilorin, Ilorin, Nigeria. \\ $*^{2}$ Department of Physics and Solar Energy, Bowen University, Iwo, Osun State, Nigeria. \\ *Corresponding Author: francisaweda@gmail.com, aweda.francis@bowenuniversity.edu.ng
}

\begin{abstract}
Trace metals and mineralogical composition of harmattan dust haze was carried out on samples collected at Ilorin $\left(8^{0} 32^{\prime} \mathrm{N}, 4^{0} 34^{\prime} \mathrm{E}\right)$ a guinea Savanna African City located at the central state of Nigeria. These dusts were gathered at different locations using clean Petri-dishes and plastic bowls of $10 \mathrm{~cm}$ in diameter. These were analyzed using X-ray Florescence (XRF) and Particle Induce X-ray Emission (PIXE) machine. The average concentration of the metals was $(13351.75 \pm 45) \mathrm{mg} / \mathrm{kg}$ and minerals $(7.22 \%)$. The mean soil content of the total size of particles for the harmattan season for the station was calculated to be $1.79765 \mu \mathrm{g} / \mathrm{m}^{3}$. In conclusion, it was observed that harmattan dusts that blow across Nigeria predominantly comprise quartz and high elements.
\end{abstract}

DOI: https://dx.doi.org/10.4314/jasem.v22i2.21

Copyright: Copyright $\odot 2018$ Falaiye and Aweda. This is an open access article distributed under the Creative Commons Attribution License (CCL), which permits unrestricted use, distribution, and reproduction in any medium, provided the original work is properly cited

Dates: Received: 10 December 2017; Revised: 29 January 2018; Accepted: 10 February 2018

Keywords: Harmattan, Ilorin, X-ray Fluorescence and Particle Induce X-ray Emission

During the period of this study (November to March), the West African region experiences the prevailing north-easterly wind regime known as Harmattan (Falaiye et al., 2003). Harmattan dust lifting, transportation and deposition, occurs naturally (Kalu, 1974, Falaiye et al., 2013). This could be as a result wind transportation that blows the dust from the source and deposition along the trajectory path (Falaiye et al., 2017).

It has been observed that harmattan season begins from November to March of the following year. This could be as result of dust that emanate from the Sahara desert which transports the dust by wind. Junge (1979) reported that on the average, it takes about twenty-four hours for the harmattan to reach the Northern part of Nigeria. As reported by Aweda et al., (2017), elements present in the harmattan dust comprise light and heavy metals. Bertrand et al., (1979) account for the dust particles deposited over the region where dust plumes predominantly originated from the Bodele depression in the Chad Basin.

\section{MATERIALS AND METHODS}

Minerals and Trace Metals analysis was carried out on harmattan dust samples gathered over Ilorin, Nigeria. This process was done using clean Petridishes and plastic bowls of $10 \mathrm{~cm}$ in diameter which were exposed on the ground level (half a metre above ground) and an elevated platform (five metres) above the ground level in twelve different locations around Ilorin metropolis including the University of Ilorin campus for five months (November to March). The samples were stored in clean desiccators prior to the analysis in order to avoid contamination. This followed what was reported by Falaiye et al., 2017and Falaiye et al., 2013.

The analysis was carried out using PIXE (Particle Induced X-ray Emission) and XRF (X-Ray Fluorescence) to determine the minerals and the trace metals present in the samples gathered across the selected locations. These were done at the Centre for Energy Research and Development (CERD), Obafemi Awolowo University, Ile-Ife, Nigeria.

Site Location: As reported by Falaiye et al., 2013 Ilorin $\left(8^{\circ} 32^{\prime} \mathrm{N}, 4^{\circ} 34^{\prime} \mathrm{E}\right)$, a guinea savanna African central state of Nigeria in West Africa, is in the transition zone between the deciduous forest of the south and the savannah of the north. Precisely, Ilorin is located at the upper tip of the guinea-savannah zone with a mean monthly average temperature of about $30.2^{\circ} \mathrm{C}$ and average annual rainfall of about $873 \mathrm{~mm}$ (Olaniran, 1991a,b) as shown in figure 1.

\section{RESULTS AND DISCUSSION}

Elemental analysis for Ilorin: Harmattan dust samples collected at Ilorin show that some elemental 
concentrations are present in the samples as shown in the table 2.

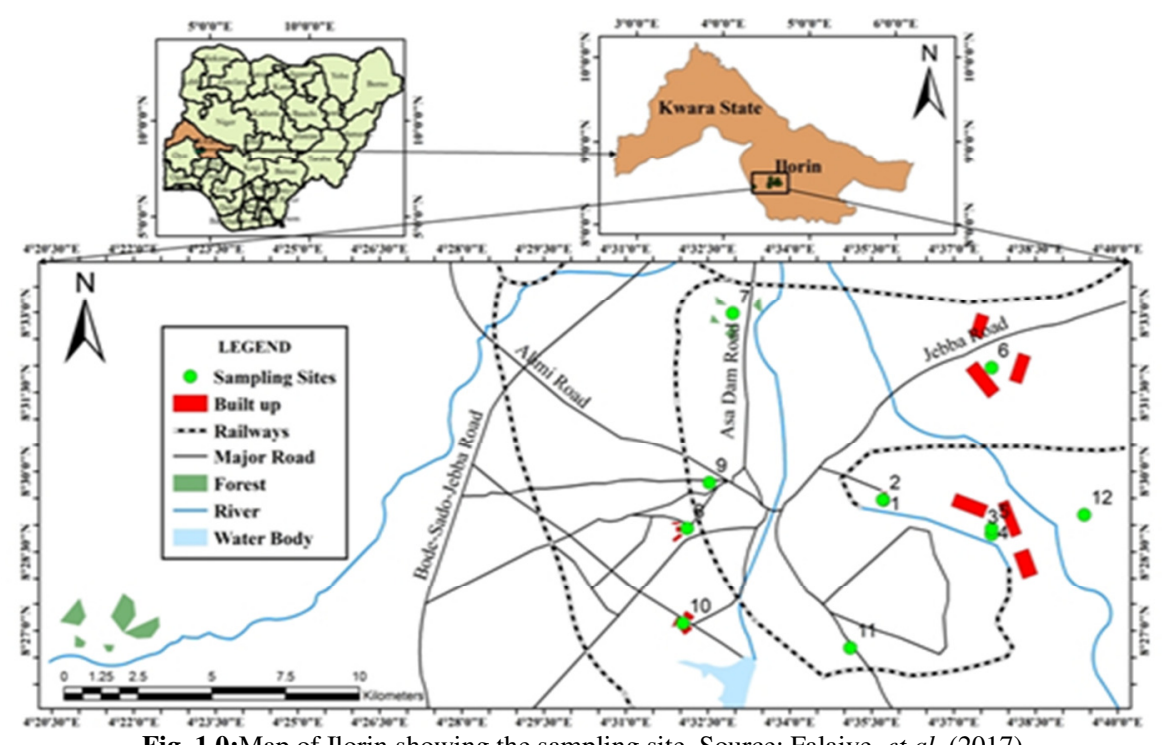

Fig. 1.0:Map of Ilorin showing the sampling site. Source: Falaiye, et al. (2017)

Table 1: Geographical Characteristics of the Ilorin

\begin{tabular}{|c|c|c|c|c|c|c|c|}
\hline $\begin{array}{l}\text { Location } \\
\text { Number }\end{array}$ & Location & $\begin{array}{l}\text { Latitude } \\
\left({ }^{0} \mathrm{~N}\right)\end{array}$ & $\begin{array}{l}\text { Longitude } \\
\left({ }^{0} \mathrm{E}\right)\end{array}$ & $\begin{array}{l}\text { Altitude } \\
(\mathrm{m})\end{array}$ & $\begin{array}{l}\text { Average Annual } \\
\text { Rainfall }(\mathrm{mm})\end{array}$ & $\begin{array}{l}\text { Climatic } \\
\text { classification }\end{array}$ & Vegetation \\
\hline 1 & Block 4 Unilorin & 8.4911 & 4.5952 & 303.89 & 1217 & $\begin{array}{l}\text { Tropical } \\
\text { hinterland }\end{array}$ & $\begin{array}{l}\text { Guinea } \\
\text { Savanna }\end{array}$ \\
\hline 2 & $\begin{array}{l}\text { Works Department } \\
\text { Unilorin }\end{array}$ & 8.4912 & 4.5951 & 303.28 & & & \\
\hline 3 & Oke-Odo & 8.4805 & 4.6282 & 284.53 & & & \\
\hline 4 & Tanke Tipper Garage & 8.4804 & 4.6282 & 281.94 & & & \\
\hline 5 & GRA & 8.4822 & 4.6283 & 285.92 & & & \\
\hline 6 & Zango & 8.5327 & 4.6282 & 291.89 & & & \\
\hline 7 & Taiwo & 8.5497 & 4.5493 & 303.89 & & & \\
\hline 8 & Saw mill & 8.4823 & 4.5354 & 302.98 & & & \\
\hline 9 & Gari-Alimi & 8.4965 & 4.5422 & 303.78 & & & \\
\hline 10 & Oja-Oba & 8.4524 & 4.5341 & 252.98 & & & \\
\hline 11 & Olunlade & 8.444698 & 4.585178 & 333.00 & & & \\
\hline 12 & Post Office & 8.4865 & 4.6565 & 300.56 & & & \\
\hline
\end{tabular}

The elements present include $\mathrm{Cu}, \mathrm{Zn}, \mathrm{Fe}, \mathrm{Pb}, \mathrm{Ca}, \mathrm{Cr}$, $\mathrm{Mn}, \mathrm{Ni}, \mathrm{As}, \mathrm{K}, \mathrm{Ti}, \mathrm{Mo}, \mathrm{V}, \mathrm{Sr}, \mathrm{Zr}$ and $\mathrm{Ce}$. They were observed in the samples collected at Ilorin using XRF machine at OAU Ile-Ife. It was observed that $\mathrm{Fe}$ has $113086 \mathrm{mg} / \mathrm{kg}$ and $52.94 \%$ concentration value of the harmattan dust samples collected at Ilorin; it was followed by $\mathrm{Ca}$ with value of $42314 \mathrm{mg} / \mathrm{kg}$ and $19.81 \%$ concentration value of the sample. $\mathrm{K}$ has $42030 \mathrm{mg} / \mathrm{kg}$ concentration value with $19.67 \%$ value of the elemental concentration. Ti has $8719 \mathrm{mg} / \mathrm{kg}$ with $4.08 \%$ concentration present in the sample. More so, $\mathrm{Mn}$ has $3479 \mathrm{mg} / \mathrm{kg}$ with $1.63 \%$ concentration present in the sample. $\mathrm{Zn}$ has $875 \mathrm{mg} / \mathrm{kg}$ with percentage concentration of $0.41 \%$ present in the sample collected. Ce has $688 \mathrm{mg} / \mathrm{kg}$ with $0.32 \%$ concentration. Zrhas $673 \mathrm{mg} / \mathrm{kg}$ with $0.32 \%$ of concentration value. $\mathrm{V}$ has $648 \mathrm{mg} / \mathrm{kg}$ with $0.30 \%$ present in the sample collected. $\mathrm{Pb}$ has
$260 \mathrm{mg} / \mathrm{kg}$ with $0.12 \%$ of concentration present in the sample. Ni has $217 \mathrm{mg} / \mathrm{kg}$ with $0.01 \%$ while $\mathrm{Cu}$ has $193 \mathrm{mg} / \mathrm{kg}$ with $0.09 \%$ of concentration. Sr has $69 \mathrm{mg} / \mathrm{kg}$ with $0.03 \%$ of concentration. Mo has $59 \mathrm{mg} / \mathrm{kg}$ with $0.03 \%$ of concentration in the sample collected. The element As is the last element found in the sample collected at Ilorin with the concentration value of $48 \mathrm{mg} / \mathrm{kg}$ and $0.02 \%$.

These elements followed the order $\mathrm{Fe}>\mathrm{Ca}>\mathrm{K}>\mathrm{Ti}>\mathrm{Zn}>\mathrm{Zr}>\mathrm{Ce}>\mathrm{V}>\mathrm{Cr}>\mathrm{Pb}>\mathrm{Ni}>\mathrm{Cu}>\mathrm{Sr}>\mathrm{Mo}$ $>$ As. According to Table 2.0 below as reported by Schwela et al 2002, it was observed that road transport emission sources include motor vehicle emission and this emission elements include $\mathrm{Pb}, \mathrm{Mn}$, $\mathrm{Zn}, \mathrm{V}, \mathrm{Ni}$ and As. Engine wear emission is Fe present in the sample. Catalytic converter emission elements were not detected in the sample collected at Ilorin. 
Tyre wear emission elements were not also detected in the sample. Nonferrous metal smelters elements present in the sample are $\mathrm{Cu}, \mathrm{As}, \mathrm{Zn}$ and $\mathrm{Pb}$. Iron and steel mills elements presents in the sample are $\mathrm{Zn}$ and $\mathrm{Pb}$. Copper refinery elements present in the sample are $\mathrm{Cu}$ and $\mathrm{Zn}$. Refuse incineration element present are $\mathrm{Zn}, \mathrm{Pb} \mathrm{Cu}$ and $\mathrm{K}$. Mineral and material processing elements present in the sample collected are $\mathrm{K}, \mathrm{Fe}$ and $\mathrm{Mn}$. Sea spray element is K. Resuspended soil elements include $\mathrm{Ca}, \mathrm{Fe}, \mathrm{Ti}, \mathrm{Sr}$ and $\mathrm{Mn}$. Road side dusts emission elements detected in the sample include $\mathrm{Ca}, \mathrm{Ti}, \mathrm{Fe}, \mathrm{Zn}$ and $\mathrm{K}$. industrial facilities emission elements that were present in the sample collected are oil fire power plants elements such as $\mathrm{V}$ and $\mathrm{Ni}$. Coal combustion elements present in the sample include $\mathrm{Ar}, \mathrm{Cu}$ and $\mathrm{C}$. Oil refineries element present is $\mathrm{V}$ as shown in the table 3

Table 2. X-Ray Fluorescence (XRF) Laboratory Analysis Report for Ilorin

\begin{tabular}{ll}
\hline Elements & Conc. $(\mathbf{m g} / \mathbf{k g})$ \\
\hline $\mathrm{K}$ & $42030 \pm 100$ \\
$\mathrm{Ca}$ & $42314 \pm 100$ \\
$\mathrm{Ti}$ & $8719 \pm 100$ \\
$\mathrm{Cr}$ & $270 \pm 21$ \\
$\mathrm{Mn}$ & $3479 \pm 68$ \\
$\mathrm{Fe}$ & $113086 \pm 100$ \\
$\mathrm{Ni}$ & $217 \pm 15$ \\
$\mathrm{Cu}$ & $193 \pm 9$ \\
$\mathrm{Zn}$ & $875 \pm 25$ \\
$\mathrm{Mo}$ & $59 \pm 10$ \\
$\mathrm{As}$ & $48 \pm 5$ \\
$\mathrm{Ce}$ & $688 \pm 77$ \\
$\mathrm{Zr}$ & $673 \pm 27$ \\
$\mathrm{~Pb}$ & $260 \pm 23$ \\
$\mathrm{~V}$ & $648 \pm 38$ \\
$\mathrm{Sr}$ & $69 \pm 7$ \\
\hline
\end{tabular}

Soil Mass Concentrations: Zhang et al., (2010) calculated the soil mass concentration of elements using the formula proposed by Malm et al., (1994).Soil mass concentrations of aerosols can be estimated by summing the concentrations of several elements in soil, and oxygen assuming that the compounds involved are mostly common oxides. The formula recommended for the calculation of soil mass concentration by elemental concentrations is as follows:

$Y_{\text {soil }}=2.2 Y_{A l}+2.49 Y_{S i}+1.63 Y_{C a}+2.42 Y_{F e}+1.94 Y_{T i} \quad 1.0$

Where $Y_{u}$ represents concentration and the names of crustal elements are shown as subscripts as u.

Table 4 shows the calculation for the soil mass concentration using equation 1.0 above. The mean soil content of total size particle for the harmattan for Ilorin was calculated to be $1.79765 \mu \mathrm{g} / \mathrm{m}^{3}$. This can be attributed to higher value of Calcium (Ca), Iron $(\mathrm{Fe})$ and Titanium $(\mathrm{Ti})$ collected during the period of the harmattan season. This could be as a result of much of human activities taking place during the period of sample collection.

PIXE (Particle Induced X-ray Emission) Method: The results of harmattan dust sample mineral collected across Ilorin for the period of study are presented in tables 1 and 5. These results show the lower and higher elements present in the sample collected and the oxides of harmattan. The heavy grouped minerals are having specific gravity greater than 2.88 ( S.G > 2.88), the Quartz minerals have specific gravity less than 2.88 but are greater than 2.62Jimoh (2012). The feldspar minerals grouped have specific gravity less than 2.62Jimoh (2012). The minerals that have specific gravity greater than 2.59 but less than 2.62 are known as Fraction B (Jimoh 2012). The minerals that have specific gravity greater than 2.50 but less than 2.59 are Fraction D minerals (Jimoh 2012). Fraction E minerals are those with specific gravity greater than 2.0 but less than 2.50 (Jimoh 2012). Those minerals that have specific gravity less than 2.0 together with the organic material are known as Fraction $\mathrm{F}$ minerals (Jimoh 2012). The mineralogical study of harmattan dust sample collected at Ilorin was analyzed and it was observed that minerals such as Quartz $\left[\mathrm{SiO}_{2}\right]$ $(77.07 \%)$ with specific gravity 2.65 predominantly dominate the sample. Some minerals present are lower or in small amount quantity of trace mineral. These minerals include, Corundum $\left[\mathrm{Al}_{2} \mathrm{O}_{3}\right](8.25 \%)$, Hematite $\left[\mathrm{Fe}_{2} \mathrm{O}_{3}\right](8.11 \%)$, Lime [CaO] $(1.97 \%)$. Minerals such as Periclase $[\mathrm{MgO}](0.42 \%)$, Rutile $\left[\mathrm{TiO}_{2}\right](0.51 \%)$, Zincite $[\mathrm{MnO}](0.09 \%)$, Montroydite $[\mathrm{HgO}](0.001 \%)$, Cuprite $\left[\mathrm{Cu}_{2} \mathrm{O}\right](0.004 \%)$, Zincite $[\mathrm{ZnO}](0.11 \%)$, Baddeleyite $\left[\mathrm{ZrO}_{2}\right](0.08 \%)$, Litharge $[\mathrm{PbO}](0.001 \%)$, Monazite $\left[\mathrm{P}_{2} \mathrm{O}_{5}\right](0.18 \%)$, while, minerals such as Petzite $\left[\mathrm{Au}_{2} \mathrm{O}_{3}\right]$, Bunsenite [NiO] had zero or no percentage concentration.

Mineralogical analysis of Ilorin: Studies have shown that the harmattan dust mineralogies have major components such as; quartz, haematite, illite, micas feldspars, kaolinite, chlorite and other accessory minerals as reported by Jimoh (2013), Falaiye et al., (2013) and Adedokun et al., (1989). It was reported by Falaiye et al., (2013) that minerals such as quartz, gibbsite, rutile, goethite, halloysite and kaolinite were detected at Ilorin using X-ray Diffraction (XRD) machine. Quartz, Hallosite, microcline and mica were similarly identified in the harmattan dust sample collected at Ile-Ife. Minerals such as quartz, gibbsite, rutile, and goethite were major minerals detected at Ilorin using XRD machine as reported by Falaiye et 
al., 2013 while for Ile-Ife (Adedokun et al., 1989) minerals such as quartz were detected as compared with what was found at Ilorin using PIXE

Table 3.Elements emitted from particle sources

\begin{tabular}{|c|c|c|}
\hline Emission Source & $\begin{array}{c}\text { Characteristic E lements Emitted } \\
\text { World Health Organization (WHO). }\end{array}$ & $\begin{array}{c}\text { E lements Emitted } \\
\text { Ilorin }\end{array}$ \\
\hline $\begin{array}{l}\text { Road transp ort } \\
\text { Motor vehicle emis sions } \\
\text { Engine wear } \\
\text { Catalytic converters } \\
\text { Tyre wear } \\
\text { Road side dusts }\end{array}$ & $\begin{array}{l}\mathrm{Br}, \mathrm{Pb}, \mathrm{Ba}, \mathrm{Mn}, \mathrm{Cl}, \mathrm{Zn}, \mathrm{V}, \mathrm{Ni}, \mathrm{Se}, \mathrm{Sb}, \mathrm{As} \\
\mathrm{Fe}, \mathrm{A} 1 \\
\text { Rare earths, } \mathrm{Pt} \\
\mathrm{ZnO} \text {, carbon black } \\
\mathrm{EC}, \mathrm{A} 1, \mathrm{Si}, \mathrm{K}, \mathrm{Ca}, \mathrm{Ti}, \mathrm{Fe}, \mathrm{Zn}\end{array}$ & $\begin{array}{l}\mathrm{Pb}, \mathrm{Mn}, \mathrm{Zn}, \mathrm{V}, \mathrm{Ni}, \mathrm{As} \\
\mathrm{Fe} \\
\mathrm{ND} \\
\mathrm{ND} \\
\mathrm{Ca}, \mathrm{Ti}_{1}, \mathrm{Fe}, \mathrm{Zn}, \mathrm{K}\end{array}$ \\
\hline $\begin{array}{l}\text { Industrial facilities } \\
\text { Oil fire power plants } \\
\text { Coal combustion } \\
\text { Oil Refineries } \\
\text { Nonferrous metal smelters } \\
\text { Iron and steel mills } \\
\text { Copper refinery } \\
\text { Refuse incineration } \\
\text { Mineral and material processing } \\
\text { Sea spray } \\
\text { Re-suspended soil }\end{array}$ & $\begin{array}{l}\mathrm{V}, \mathrm{Ni} \\
\mathrm{Se}, \mathrm{As}, \mathrm{Cr}, \mathrm{Co}, \mathrm{Cv}, \mathrm{Al}, \mathrm{S}, \mathrm{P}, \mathrm{Ga} \\
\mathrm{V} \\
\mathrm{As}, \mathrm{Sb}, \mathrm{Cv}, \mathrm{Zn}, \mathrm{Pb}, \mathrm{Cd}, \mathrm{Hg} \\
\mathrm{Zn}, \mathrm{Pb} \\
\mathrm{Cv}, \mathrm{Zn} \\
\mathrm{Zn}, \mathrm{Pb}, \mathrm{Cv}, \mathrm{Cd}, \mathrm{Hg}, \mathrm{K} \\
\mathrm{Si}, \mathrm{Al}, \mathrm{Ca}, \mathrm{Mg}, \mathrm{K}, \mathrm{Sc}, \mathrm{Fe}, \mathrm{Mn} \\
\mathrm{Na}, \mathrm{Cl}, \mathrm{S}, \mathrm{K} \\
\mathrm{Si}, \mathrm{Al}, \mathrm{Ca}, \mathrm{Mg}, \mathrm{Fe}, \mathrm{T}_{1}, \mathrm{Sr}, \mathrm{Mn}, \mathrm{Sc}\end{array}$ & $\begin{array}{l}\mathrm{V}, \mathrm{Ni} \\
\mathrm{As}, \mathrm{Cu} \\
\mathrm{V} \\
\mathrm{As}, \mathrm{Cv}, \mathrm{Zn}, \mathrm{Pb} \\
\mathrm{Zn}, \mathrm{Pb} \\
\mathrm{Cv}, \mathrm{Zn} \\
\mathrm{Zn}, \mathrm{Pb}, \mathrm{Cu}, \mathrm{K} \\
\mathrm{Ca}, \mathrm{K}, \mathrm{Fe}, \mathrm{Mn} \\
\mathrm{K} \\
\mathrm{Ca}, \mathrm{Fe}, \mathrm{T}_{1}, \mathrm{Sr}, \mathrm{Mn}\end{array}$ \\
\hline
\end{tabular}

Source: Adapted from Guidelines for concentration and exposure-response measurement of fine and ultra-fine particulate matter for use in epidemiological studies. Schwela, et al., 2002.World Health Organization (WHO). ND Means: Not Detected

Table 4. Soil Mass Concentration Elements

\begin{tabular}{ccccccc}
\hline Location & $C_{A l}\left(\mu \mathrm{g} / \mathrm{m}^{3}\right)$ & $C_{S i}\left(\mu \mathrm{g} / \mathrm{m}^{3}\right)$ & $C_{C a}\left(\mu \mathrm{g} / \mathrm{m}^{3}\right)$ & $C_{F e}\left(\mu g / \mathrm{m}^{3}\right)$ & $C_{T i}\left(\mu g / \mathrm{m}^{3}\right)$ & $C_{\text {soil }}\left(\mu g / \mathrm{m}^{3}\right)$ \\
\hline Ilorin & $\mathrm{ND}$ & $\mathrm{ND}$ & 0.6897 & 2.7367 & 0.1691 & 3.5951 \\
\hline
\end{tabular}

Table 5: Percentage Proportion of Minerals Present in Harmattan Dust at Ilorin Compared To that of Ile-Ife (Adedokun et al., 1989) and Ilorin using XRD Machine (Falaiye et al., 2013)

\begin{tabular}{|c|c|c|c|c|}
\hline Mineral & Specific Gravity & Ilorin, (\%) & Ile-Ife, (\%) & Ilorin (PIXE) (\%) \\
\hline 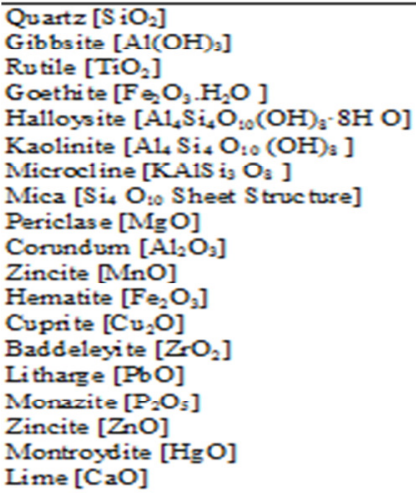 & $\begin{array}{c}2.65 \\
2.35 \\
4.2 \\
4.4 .2 \\
2.6 \\
2.6 \\
2.56 \\
2.7-3.1 \\
3.56 \\
4.0-4.2 \\
5.66 \\
5.26 \\
6.13-6.15 \\
5.4-6.02 \\
9.14 \\
4.6-5.4 \\
5.66 \\
11.23 \\
1.97\end{array}$ & $\begin{array}{l}76.47 \\
7.09 \\
5.78 \\
4.59 \\
3.93 \\
2.09 \\
- \\
- \\
- \\
- \\
- \\
- \\
- \\
- \\
- \\
- \\
- \\
-\end{array}$ & $\begin{array}{c}74.78 \\
- \\
- \\
1.45 \\
10.29 \\
17.63 \\
2.54 \\
- \\
- \\
- \\
- \\
- \\
- \\
- \\
- \\
- \\
- \\
-\end{array}$ & $\begin{array}{c}77.07 \\
7.42 \\
0.51 \\
2.65 \\
- \\
- \\
- \\
- \\
0.42 \\
8.25 \\
0.11 \\
8.11 \\
0.04 \\
0.08 \\
0.001 \\
0.18 \\
0.09 \\
0.01 \\
3.3\end{array}$ \\
\hline
\end{tabular}

Source of Specific Gravity: Read, 1973

It was observed that minerals such as halloysite, kaolinite were observed at Ilorin and Ile-Ife as reported by Falaiye et al., 2013 and Adedokun et al., 1989, while minerals such as microcline and mica were observed at Ile-Ife which were not observed at Ilorin as reported by Falaiye et al., 2013.It was observed that minerals such as periclase, corundum, zincite, hematite, cuprite, baddeleyite, litharge, monazite, zincite, montroydite and lime were observed in the sample collected at Ilorin which could be as a result of PIXE machine used for this research work. As expected, it is observed that PIXE machine can detect many minerals as shown in the sample gathered. All these could be as a result of Ilorin being a central/middle state of Nigeria which could observe more minerals as compared with IleIfe as reported by Adedokun et al., 1989. The result shows that quartz is the dominant as its constituents have an average value of $77.07 \%$ as compared with Adedokun et al., 1989 and Falaiye, et al., 2013, which was also observed to be high percentage proportion. This shows that the harmattan that blows across Nigeria has much of quartz mineral which could be as a result of dust that emanated from the 
Sahara desert. But other minerals are present either in small quantities or trace as shown in the table 5 above. These results are in line with what was observed at Ile-Ife (Adedokun et al., 1989) and Ilorin (Falaiye et al., 2013), except that mica and microcline were not detected in Ilorin as reported by (Falaiye et al., 2013) and this study. It was observed that $\mathrm{NaO}(0.60 \%), \mathrm{Cl}(0.18 \%), \mathrm{K}_{2} \mathrm{O}(2.34 \%), \mathrm{Cr}_{2} \mathrm{O}_{3}$ $(0.02 \%), \mathrm{Rb}_{2}(0.003 \%), \mathrm{Nb}_{2} \mathrm{O}_{5}(0.009 \%)$ were oxide present in the sample without minerals, while oxides with zero percentage value include $\mathrm{SO}_{3}, \mathrm{Sc}_{2} \mathrm{O}_{5}, \mathrm{~V}_{2} \mathrm{O}_{3}$, $\mathrm{As}_{2} \mathrm{O}_{5}$ and $\mathrm{BaO}$. The percentage oxides of the mineral present in the sample shows that Quartz is the major constituent of minerals collected at Ilorin. It was observed that if some oxides are combined they produce minerals such as Geikielite $\left[\mathrm{MgTiO}_{3}\right]$, Perovskite $\left[\mathrm{CaTiO}_{3}\right]$, Zinnmetatitanate $\left[\mathrm{ZnTiO}_{3}\right]$ and nickel titanium oxide $\left[\mathrm{NiTiO}_{3}\right]$. This shows that the combination of $\mathrm{TiO}_{2}$ produces some other minerals. The oxides gotten from the harmattan dust sample collected at Ilorin were as a result of PIXE machine.

Conclusion: Atmospheric aerosol and mineral dust production are as a result of desert dust that emanated from the Sahara. These amount to the largest dust production of the global aerosol loading and have strong impact on climate change and reduction in the visibility of both human and animal as the case may be. Therefore, it could be observed that the Sahara is the major contribution of the earth aerosol and minerals dust. This shows that the mineral composition of the harmattan dust at each location is as a result of source and distance from the harmattan dust sample.

Acknowledgement: For this research, the author's wish to acknowledge the Center for Energy Research and Development (CERD) located at Obafemi Awolowo University for the privilege given towards the analysis of sample.

\section{REFERENCES}

Adedokun, JA; Emofurieta, WO; Adedeji, O A (1989). Physical, Mineralogical and Chemical Prosperities of harmattan Dust at Ile-Ife, Nigeria. Theor. Appl. Climatol. 40. 161-169.

Aweda, FO; Falaiye, OA; Babatunde, JG (2017).Elemental Concentration of Harmattan Dust Sample in Iwo and Oyo Town, South West Nigeria. J. Appl. Sci. Environ. Manage. 21(7):1313-1316.

Bertrand, J; Cerf, A and Domergue, JK (1979). Repartition in Space and Time of Dust Haze South of the Sahara, W.M.D. 538, pp 409-415.
Falaiye, OA; Aro, TO and Babatunde, EB (2003). Inter-annual Variation of Aerosol Optical Depth at Ilorin $\left(8^{\circ} 32 \mathrm{~N}, 4^{\circ} 34\right.$ ?E), a Central State of Nigeria, Zuma J. Pure Appl. Sci.5 (2) 197-204.

Falaiye, OA; Yakubu, A T; Aweda, FO; Abimbola, OJ (2013). MineralogicalCharacteristics of Harmattan Dust in Ilorin, Sub-Sahara Africa. Ife J. Sci. 15 (1) 175-181.

Falaiye, OA; Aweda, FO and Yakubu, A T (2017). Harmattan Dust Mass Over Ilorin a Guinea Savanna African City. FUTA J. Res. Sci. 13(1):158- 167.

Jimoh, WLO (2012).Chemical Composition and Mineralogy of Harmattan Dust from Kanoand Zaria Cities in Northern Nigeria, Res. J. Environ. Earth Sci. 4(4): 428-433.

Junge, C (1979). The importance of mineral dust as atmospheric constituents. Scientific Committee on Problems of the Environment. SCOPE Report: 14, John Wiley and sons, Chichester and New York.

Kalu, AE (1979). The African dust plume: Its characteristics and propagation across West Africa in winter. In Morales, C. (Ed.) Saharan dust Mobilization Transport Deposit, SCOPE 14, John Wiley, 95-118.

Malm, WC; Sisler, JF; Huffman, D; Eldred, RA and Cahill, TA (1994). Spatial and Seasonal Trends in Particle Concentration and Optical Extinction in the United States. J. Geophysics. Res. 99: 1347-1370.

Olaniran, OJ (1991a). Rainfall Anomaly Patterns in Dry and Wet Years over Nigeria. Int. J. Climate. 11: 177-204.

Olaniran, OJ (1991b). Evidence of Climatic Change in Nigeria Based on Annual Series of Rainfall of Different Daily Amounts, 1919-1985. Climatic Change 19: 319-341.

Read, HH (1973). Rutley Elements of Mineralogy. $26^{\text {th }}$ Edition Jolly and Barber Ltd., Rugby. Great Britain.

Zhang, R; Shen, Z; Cheng, T; Zhang, M and Liu, Y (2010). The Elemental Composition of Atmospheric Particles at Beijing during Asian Dust Events in spring 2004.Aerosol Air Qual. Res. 10: 67-75. 